IFN Working Paper No. 720, 2007

\title{
Economic-Social Interaction in China
}

\author{
Assar Lindbeck
}




\title{
Economic-Social Interaction in China ${ }^{1}$
}

\author{
Assar Lindbeck \\ Institute for International Economic Studies \\ Stockholm University \\ SE-106 91 Stockholm, Sweden, and \\ Research Institute of Industrial Economics, Stockholm \\ E-mail: assar@iies.su.se
}

\begin{abstract}
This paper analyzes economic-social interaction in China in connection with the country's change of economic system. I define an economic system in terms of a multidimensional vector of broad institutional characteristics, and I emphasize that important features of the social development are closely related to specific changes in these various dimensions. I classify China's options for future social improvements into three broad categories: policies that improve the stability and distribution of factor income; government-created wedges between factor income and disposable income; and improvements in the quantity, quality and distribution of human services, such as education and health care.
\end{abstract}

JEL classifications: P2, H00, I00.

Keywords: China, economic transition, typology of economic systems, social reforms.

\footnotetext{
${ }^{1}$ The paper builds on my keynote speech at the meeting of the Chinese Economist Society in Shanghai July 2006. Lindbeck (2006a) provides richer references to data sources and the literature. I am grateful to Harry Flam, Nannan Lundin and Solveig Wikström for useful comments on a draft of the paper. Financial support from Jan Wallander and Tom Hedelius’ Research Foundation is gratefully acknowledged.
} 


\section{Economic-Social Interaction in China}

China's highly successful economic transition during the last three decades, with an officially reported GDP growth rate of 9.5 percent per year since 1980, has been accompanied by huge and complex social change. ${ }^{2}$ I refer, in particular, to changes in the incidence of poverty, the security and distribution of income, employment opportunities and the provision of human services such as education and health care. The development in these areas raises the issue of China's future policy options to improve social conditions; indeed, this is the basic topic of the paper. First, however, it is important to be clear about the nature of the economic transition.

\section{The nature of the economic transition}

Since the economic reforms in China imply a radical, although gradual, change of the country's economic system, it is useful to analyze the reforms in the context of a typology of economic systems. To this end, I regard an economic system as a multi-dimensional phenomenon, defined in terms of a nine-dimensional vector of broad institutional characteristics; see Figure $1 .^{3}$ The first two dimensions concern ownership of firms and assets, respectively - contrasting public (government) and private ownership. The third dimension deals with the choice between centralized and decentralized economic decisionmaking, and the fourth with the related choice between administrative processes and market mechanisms for transmitting information, coordinating economic decisions, and distributing goods and services among households. The fifth and sixth dimensions concern the extent to which economic behavior is influenced by non-economic motives and economic incentives, respectively - in the case of individuals as well as firms. The seventh and eighth dimensions

\footnotetext{
${ }^{2}$ Some outside specialists in national accounting report lower figures for China's GDP growth rate. According to Maddison (2003) and Young (2003), 7.5 percent per year is a more realistic figure.

${ }^{3}$ I follow a classification of economic systems in Lindbeck (1975).
} 
Figure 1

Dimensions of economic systems

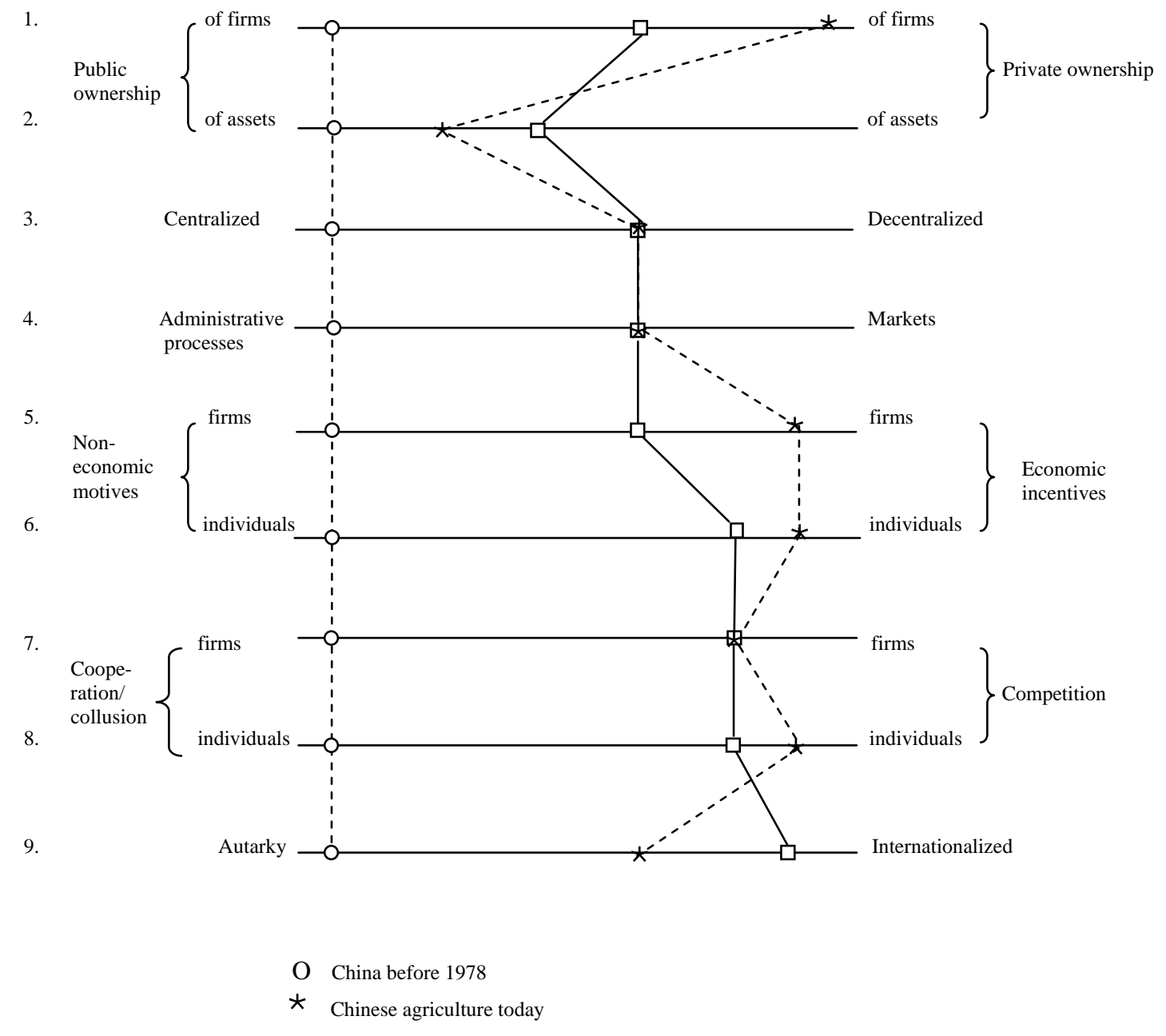

Chinese non-agriculture sectors today 
refer to a crucial aspect of the relation between economic agents in the domestic economy: the role of competition. The ninth dimension, finally, concerns the relations between domestic economic agents and the outside world, contrasting autarkic and internationally integrated (“internationalized”) economic systems.

I depict the initial (“standardized”) position of China's economic system in the late 1970s by the vertical vector of circles to the far left in the figure. Today's position (in 2007) is schematically described by stars in the case of agriculture, and by squares for the rest of the economy. In terms of this diagram, the economic system has gradually shifted to the right in all dimensions - towards private ownership of firms and assets, decentralized decisionmaking of production and consumption to firms and households respectively, and increased reliance on markets, economic incentives, competition and international economic interaction (codified in China's entry into WTO in year 2001). Although each dimension is conceptually distinct from the others, several of them are strongly interdependent. An obvious example is that market mechanisms fulfill the role of coordinating decentralized decision-making by firms and households. There are also complex interrelations between ownership and other dimensions of the economic system. In particular, public ownership makes it easier, perhaps also more tempting, for politicians and public-sector administrators to centralize decisionmaking and restrict the operations of markets.

In the figure, I have also schematically indicated the relative magnitude of the shifts in different dimensions of the economic system. Except for the second and ninth dimensions asset ownership and internationalization - the reforms seem, so far, to have advanced further in agriculture than in industry. ${ }^{4}$ The reason is largely that politicians and public-sector administrators still routinely intervene in state-owned enterprises (SOEs) in industry, services and financial institutions. Needless to say, the figure is only illustrative. (When I see no specific reason for asserting that a shift is larger in one dimension than in another, or in one sector than in another, the shifts are simply depicted as having the same size in both cases.)

This disaggregation of the concept of an economic system reminds us that the traditional distinction between capitalism and socialism is too blunt for a constructive analysis of economic systems. Moreover, as will be emphasized below, important features of the social development in China in recent decades turn out to be closely related to changes in specific

\footnotetext{
${ }^{4}$ For a discussion, see Lindbeck (2006a, pp. 9-17).
} 
dimensions of the country's economic system. In this sense, contemporary suggestions of social reforms are largely triggered by, and have to be adjusted to, China's shift to a new economic system.

How, then, should today's economic system in China be labeled? Some observers call it "state capitalism". While this label may have been appropriate (outside agriculture) in the 1980s, it is rather misleading today. The bulk of production today takes place in private firms, including privately owned Town and Village Enterprises (TVEs) and firms controlled by foreign (non-mainland) owners. For instance, OECD (2005a, Table 2.1) estimates that about 60 percent of aggregate production in China in 2004 was accounted for by the private sector. ${ }^{5}$ The term "market socialism", although recently often used by the Chinese authorities, is also misleading. After all, dominating models of market socialism - such as those developed by Oskar Lange (1938) and Abba Lerner (1934) - presuppose public ownership of firms. In some models of market socialism, such as that of Lange, prices are also supposed to be determined by the government, while most prices in China are today formed on markets, the main exceptions being natural resources and public utilities. Moreover, the label "socialism" is usually not associated with a strong reliance on economic incentives, competition, internationalization and (as in China) an apparent neglect of the distribution across households of income, education and health care.

For these reasons, it is perhaps most appropriate to simply characterize today's economic system in China as a kind of "mixed economy", although with a number of specific features, such as less private ownership of assets than of firms (in particular, in agriculture); frequent ad hoc government interventions in public-sector firms; less developed factor markets than product markets; and an important role for informal business networks, guanxi. The guanxi, which often also includes politicians and public-sector administrators, partly compensates for deficiencies in "the rule of law" in the country. However, the guanxi is a mixed blessing. It contributes to an insider-outsider division of the business community and, as will be emphasized below, it keeps the doors open to corruption.

\section{Social consequences}

China's economic transition since the late 1970s has been accompanied by pronounced social achievements as well as serious social problems. The sevenfold increase in per capita

\footnotetext{
${ }^{5}$ In a speech to the congress of the Chinese Economists Society in Shanghai, July 3, 2006, the Deputy Finance Minister of China, Jiwei Lou, stated that private firms account for 70 percent of aggregate output.
} 
income for a billion of some of the poorest people in the world, and the related dramatic fall in the incidence of deep ("absolute”) poverty, are perhaps the most obvious social achievements. ${ }^{6}$ It is also natural to regard the increase in economic (in contrast to political) freedom of individuals as a major social achievement: the right to choose profession, employer and consumption bundle, as well as to set up a business and become an entrepreneur. However, it is also easy to identify a number of remaining, and in some cases deteriorating, social problems during the period of economic transition - problems that constitute a natural background to a discussion of China's policy options for improving social conditions in the country.

\section{The breakdown of previous social arrangements}

With only slight exaggeration, we could say that the division of tasks between the government and firms, or rather work units (danwei), during the pre-reform period was the reverse of the corresponding division in developed countries today. While the government was in charge of basic production decisions (a primitive type of input-output planning), work units functioned as mini-welfare states, or "enterprises running small societies” (Xiaoyi, 1996). It is hardly surprising that the shift to competitive markets made it difficult for the work units to fulfill the assigned social obligations. Many firms could simply no longer afford to guarantee jobs, pay cash benefits (including pensions) or provide "human services" to their employees - such as health care, housing and elementary education for the employees' children. Moreover, benefits tied to specific work places do not sit well in a market economy, since an efficiently functioning labor market requires social benefits to be highly portable. The move to a competitive market, and the increased reliance on economic incentives, also meant that income-insecurity increased, including a rise in unemployment risks. Hence, while income protection deteriorated, the need for such protection increased.

As many observers have pointed out, acute social problems in urban areas were mitigated during the first phase of the economic transition thanks to the gradualist nature of the economic reforms. In particular, this helped the country avoid a "transition depression" - in contrast to what happened in most other transition economies. ${ }^{7}$ Moreover, ad hoc selective capital transfers from the government and "social” loans from state banks functioned as stopgap solutions helping state firms live up to at least some of their social obligations, including

\footnotetext{
${ }^{6}$ The incidence of absolute poverty, defined as the fraction of the population with an income of less than (about) one dollar a day, is estimated to have fallen from about 50 percent to less than 10 percent between 1981 and 2004 (World Development Indicators, 2006).
} 
their "job guarantees". However, this did not only increase the volume of "soft" and, indeed, often non-performing loans, with negative consequences for the stability of financial institutions. It also accentuated the discrimination of private firms in financial markets, since the loans to state firms drained the lending to other firms, with negative consequences for the ability of domestic private firms to expand production and employment. The "double bind" state firms constrained in shedding labor and private firms constrained in acquiring loans implied a kind of catch-22 situation during much of the reform period. It has been difficult to remove this double bind as long as private firms are not able to expand their employment sufficiently to absorb redundant workers in state firms and workers exiting agriculture - and before new arrangements for income protection are in place. The negative consequences of these policies for the development of aggregate employment have been accentuated by China's highly capital-intensive growth strategy. ${ }^{8}$

The social consequences of the new role of work units were even stronger in rural than in urban areas. Indeed, the shift from agriculture communes to family farms implied that the earlier existing social arrangements in rural areas largely disappeared - in the case of income protection as well as human services, in particular, health care.

Inadvertently, during the reform period, households also indirectly helped finance the social obligations of state firms, since households' deposits in state banks (at low, and during some periods even negative, real interest rates) have been intermediated into low-interest loans to state firms. As a result, the social obligations of state firms have, in fact, been partly financed by an "inflation tax" on households' financial savings (although less so during years with low inflation). This, in turn, implies that much of the real return on household savings has been transferred to the beneficiaries of various social arrangements - much like a taxfinanced pay-as-you-go system, although in this case the "tax" has been imposed on the return on savings rather than on work.

Moreover, surviving privileges for employees in state firms - in terms of wages as well as social benefits of various types - have created a pronounced insider-outsider character also for the urban labor market. ${ }^{9}$ This character has been accentuated by the residence registration

\footnotetext{
${ }^{7}$ The so-called "dual track approach to transition" in China is an important example of gradualism. For a while, the old SOEs could count on previously agreed prices and deliveries - at the same time as a "new" economy emerged alongside the old one (Lau et al., 2000).

${ }^{8}$ Aggregate employment growth seems to have been no more than one percent per year between 1993 and 2004; see Kuijs and Wang (2005).

${ }^{9}$ However, the previous "job guarantees" for workers in SOEs have gradually become worth less due to large lay-offs in such firms from the mid-1990s.
} 
system, the urban hukou. Although this system has recently become less restrictive, individuals without permanent urban residence - the "floating population" - are still a strongly disadvantaged group in urban areas. They often have particularly unpleasant and dangerous jobs and they seem to be less rewarded than others in terms of the return on their human capital (Maurer-Fazio and Dinh, 2004). ${ }^{10}$ The new social arrangements created during the period of economic transition have also systematically favored "urban insiders" - leaving the "floating population", many private sector employees and rural residents behind. Indeed, as late as in 2005 most arrangements of income insurance in the country as a whole seem to have covered less than twenty percent of the workforce. ${ }^{11}$ Moreover, since the government has only slowly taken over the financing of human services, citizens have in recent years found it necessary to finance about 55 percent of the health expenditures and about 18 per cent of the spending on education from out-of-pocket money (the figures refer to 2004). ${ }^{12}$

Naturally, urbanization is also connected with social problems, and these are likely to be accentuated in the future. For instance, without any drastic intervention against motor traffic in cities, such as congestion fees, the traffic system is bound to not only run into serious inefficiencies but also to contribute to deterioration in the quality of city life and health due to pollution, crowding and noise. Indeed, such deterioration is already underway, but the worst is yet to come. Since the required policy interventions are politically easier when car owners are still a small minority, the political "window of opportunity" for dealing with these problems is likely to shrink in the future. It is also unavoidable that China gradually will run into other "typical" urban social problems such as high criminality, the misuse of drugs and alcohol, and a clustering of individuals with mental disorders in urban areas - not least in large cities.

Other important social changes are a direct consequence of recent changes in demography. So far, the so-called demographic burden for the active generation has diminished - partly a result of the one-child-policy. ${ }^{13}$ However, this "demographic dividend” will turn into a “demographic deficit” from about 2010 when the share of individuals of working age will

\footnotetext{
${ }^{10}$ The size of the floating population is today officially estimated at 147 million (China Population Statistics Yearbook 2006, p. 3)

${ }^{11}$ In 2005, unemployment insurance covered 14 percent of China's workforce, work-injury insurance 11 percent and the basic mandatory government pension scheme 17 percent (NBS, National Bureau of Statistics of China, 2006b, pp. 43 and 201). Even the social assistance program for the poor in urban areas, the so-called $D i$ Bao system ("welfare" in US terminology), is still confined to registered urban residents.

12 NBS, 2006a Tables 21-26 and 2005 Tables 12-31; Ministry of Health, 2006, Tables 4-1.

${ }^{13}$ Broadly speaking, the fertility rate has dropped from about 6.2 in 1950-1955 to about 1.7 today, and life expectancy (at birth) has increased from about 40.8 to about 72.0 years during the same period (UN, World Population Prospects, 2006).
} 
start to fall. ${ }^{14}$ Since China is "getting old before getting rich”, such demographic problems will emerge at a lower per capita income level in China than they did in today's developed and middle-income countries. While, to begin with, this burden will mainly be felt within families, in a long-term perspective (when comprehensive social insurance systems have been built up) both the pension system and public-sector arrangements for old-age care will feel the pinch of the demographic development. The aging of the population will probably also impede the long-term vitality of the economy in the future, since innovation and new entrepreneurship often thrive among young population groups. Experiences from many countries suggest that it is not easy, although not impossible, for governments to do much about the demographic situation, such as boosting fertility after it has declined substantially. ${ }^{15}$ Recent tendencies to a softening of the one-child policy are, therefore, unlikely to drastically ameliorate the demographic situation, although the distorted proportions between newborn boys and girls (1.2 today) might be modified.

\section{Distributional consequences}

It is hardly surprising that China's radical change of economic system has been accompanied by a widening of the income gap in various dimensions - across regions, between urban and rural areas (from the mid-1980s) and within geographical areas. For instance, it is a commonplace that China's open-economy strategy contributed to the huge regional income gaps to the advantage of the coastal areas - an effect accentuated by the build-up of the "Special Economic Zones” (SEZs), and a concentration of infrastructure investment to these zones. Falling terms of trade for agriculture from the late 1980, and the absence of new efficiency-enhancing agriculture reforms after the shift to farm households in the early 1980s, also contributed to widen the income gap between urban and rural areas from the mid-1980s. ${ }^{16}$ Indeed, in economic terms, China today looks less like a nation state than a continent with a mixture of middle-income industrial areas and some of the poorest areas in the world. ${ }^{17}$

\footnotetext{
${ }^{14}$ Indeed, reasonable forecasts suggest that the number of individuals of working age in 2050 will be about the same as the number of dependents (the sum of children below 18 and elderly above 60). The UNDP (2005) predicts that the population share of individuals of working age will be as low as 53 percent by 2050 - the lowest predicted share at that time among East Asian countries except Japan.

${ }^{15}$ Although the drastic fall in fertility in China has been speeded up by the one-child policy, the time path of the fertility rate does not differ drastically from the path in other East Asian countries during comparable periods of "modernization" (UNPD, 2005).

${ }^{16}$ In the early 1980s, the shift to family farms, like the immediately previous shift to the so-called "household responsibility system”, narrowed the income gap between urban and rural areas for a while. It even contributed to an overall equalization of income in China (Ravallion and Chen, 2007).

${ }^{17}$ The level of per capita GDP is currently reported to be about seven times higher in the most developed than in the least developed province, even if we exclude the very poorest province (Guizhou); see NBS 2006a, Tables 3-9. Moreover, according to official statistics, the average income in urban areas is 3.2 times higher than in rural areas (NBS, 2006b, Tables 2-27, pp. 6 and Tables 2-40 p. 72).
} 
It is also easy to understand that the shift to an incentive-based economic system contributed to widen the income gaps, since both the reward for success and the punishment for failure increased. Some individuals have simply been more successful than others in utilizing the new incentive system - depending on skills, energy, contacts, luck etc. For instance, this is reflected in the large increase in the skill premium (Blanchard and Giavazzi, 2005). The shift from price control and rationing to market-determined prices for basic consumer products also tended to redistribute real income to the disadvantage of low-income groups, for which such products constitute a relatively large fraction of their total consumption.

The shift of economic system also created new, and highly unevenly distributed, types of income: entrepreneurial income and capital income. The way firms and assets were privatized accentuated these consequences, since the ownership of firms and housing were in many cases handed over to a limited fraction of the population - at prices far below market values. Indeed, those favored by this “asset stripping” probably also had a higher than average labor income. (Of course, these distributional consequences of privatization should be compared to the contributions of the privatization process to the long-term reduction in absolute poverty - through the release of private entrepreneurship.)

Basically, the increased inequalities are also a result of the absence of comprehensive policy measures to counteract the distributional consequences of the shift of economic system. This helps explain why the Gini coefficient for the distribution of household income in China increased from 28 in 1981 to 43 in 2001; indeed, it may very well be as high as 50 today (according to reports in May 2007 in the state press). The wide dispersion of the overall distribution of income is also reflected in statistics on relative poverty, expressed, for instance, by the shares of aggregate earnings received by the poorest relative to the richest part of the population. ${ }^{18}$

\section{Weak property rights and corruption}

The earlier mentioned deficiencies in the "rule of law" have also had important social consequences during the period of economic transition. The best-known example is perhaps the expropriation of land-lease contracts held by farmers. At least 34 million farmers seem to have lost their land-lease contracts, partly or completely, between 1987 and 1991 due to the expropriation without full economic compensation (UNDP, 2005, footnote 120). Such 
expropriations have also subsequently taken place. Thus, social concerns have been relinquished for other purposes - such as a fast rate of structural change, when land-lease contracts have been handed over to developers in industry, retailing, housing etc. (Zhang, 2006). This also seems to have been a major source of corruption in rural areas, since the economic gains in connection with these transactions have often been shared between developers and local “cadres” - politicians as well as public-sector administrators; see, for instance Chow (2007). It is also difficult to avoid rampant corruption in connection with the earlier mentioned informal networks among businessmen, public sector administrators and politicians. More generally, it is difficult to get rid of corruption as long as politicians and public-sector administrators have something to sell - like permits, contracts of various types, loans and subsidies. Experiences from many countries also suggest that the absence of political democracy and a free press breed corruption (Svensson, 2005 and references therein).

Asset stripping has, however, not been "all bad”. Most likely, it has speeded up the shift to decentralized private ownership of firms and assets. This is in contrast to the development in the former Soviet Union, where the ownership of firms and assets during the transition process became concentrated to a small group of "oligarchs". However, if asset stripping and other forms of corruption become a permanent component of Chinese society, they may undermine the legitimacy of the economic system, in particular when the ensuing inequalities are unrelated to productivity-enhancing incentives. Experiences in other countries also suggest that corruption is likely to be detrimental to economic efficiency in a long-run perspective (Svensson, 2005).

\section{Options for future socially oriented policies}

It is hardly surprising that new comprehensive social arrangements - for income protection and human services - did not emerge spontaneously in China through market forces, as the old arrangements broke down. Indeed, this experience is consistent with traditional economic analysis, which highlights various limitations of spontaneous market solutions in this field. However, the political leaders in China have recently been increasingly worried about the social situation in the country - worries reflected rhetorically in promises to create a "harmonious society" and a "new socialist countryside” in the future. ${ }^{19}$ It is also tempting to

\footnotetext{
${ }^{18}$ While the poorest 10 percent of households seem to earn about 2 percent of aggregate disposable household income, the richest 10 percent earn about 35 percent (World Development Indicators, 2006).

${ }^{19}$ In particular, the coverage of health insurance programs seems to have increased recently, although the benefit levels are still very low. NBS (2007) and Ministry of Health (2007) report that about half the population
} 
speculate that the new emphasis on policies with social ambitions has been stimulated by apparent social unrest in the country, reflected in some 80,000 reported "social incidents" each year recently. Indeed, the actual pace of reform to improve the social situation in the country seems to have increased recently (from about 2005), in particular in the countryside.

What, then, are China's main future policy options for improving the social situation? When discussing this issue, it is useful to classify such policies into three broad categories: (i) policies designed to increase in the level and stability of factor income, in particular among the poorest section of the population; (ii) wider wedges between factor incomes and disposable income; and (iii) improvement in the quantity, quality and distribution of human services, such as education and health care.

\section{Factor-income policies}

Naturally, a continuation of fast GDP growth is required not only for a further rapid increase in per capita household income; it would also facilitate further fast reduction in the incidence of serious poverty. The potential importance of the latter point is illustrated by the observation that about 25 percent of the Chinese population still live on less than $\$ 2$ a day (according to World Bank calculations). However, China also has much to gain from shifting from its highly "extensive" to a more "intensive" growth path. Resources could then also be released for social purposes. One example of such a shift would be a change of the composition of investment from real capital assets to human capital. While fast GDP growth requires a large accumulation of capital, the present composition of investment between real capital assets and human capital is heavily tilted in favor of the former. For instance, while investment in real capital has recently been 43 percent of GDP, spending on education has only been 4.3 percent. Less capital-intensive production would also help keep unemployment down - another important social objective. Smaller inputs of energy and raw material per unit of GDP, and less destruction of the physical environment, would be other important examples of a shift to a more intensive growth path. The importance of dramatic improvements in environmental policies in China is, of course, well known today; see, for instance, Economy (2007). Indeed, such improvement would be an automatic consequence of less emphasis on investment in real capital assets, in particular in heavy industry, and it could be considerably accentuated by allowing much higher user-prices for such inputs (Lardy, 2006).

in urban areas was protected by compulsory health insurance in 2006, and in rural areas about the same share was covered by the voluntary cooperative health program. 
Most likely, generally improved working conditions for small firms, for instance through better functioning capital and credit markets, are also crucial for a major long-term improvement of factor income among people in rural areas. Targeted infrastructure investment in real capital assets and human capital to poor geographical areas in China are other obvious methods to boost factor income in such areas. ${ }^{20}$ (Targeted human capital investment may take many forms - not only education but also policy actions designed to improve nutrition, sanitation and basic health services among the poor population.) Against this background, it is interesting to notice recent signals by the political leaders in China of future shifts of investment from eastern provinces to poor geographical areas in the west the newly announced “Go West Strategy”. Assuming a falling marginal return on investment in both real and human capital (at least after some point), the economic costs for the country as a whole of such a shift of the geographical allocation of investment may not be very large, provided that the new investment projects are based on reasonably careful cost-benefit analysis. $^{21}$

Removal (or at least a further softening) of the urban hukou would also be expected to boost the per capita factor income of low-income groups - both among those who move to urban areas and among those who remain in the countryside (the latter effect as a result of both increased remittances from migrants and diminished labor supply in rural areas). ${ }^{22}$ The period of Arthur Lewis-type "unlimited supply of labor" (Lewis, 1954) might then be extended, at least in some urban areas. The most likely losers would be urban insiders exposed to stiffer wage competition, with an overall reduction in income inequality in the country as a whole as a result. ${ }^{23}$ During a comparable phase of industrialization, today's developed countries in Europe also experienced a huge outflow of labor from agriculture. But a considerable share of the rural population could then migrate to other continents with ample availability of agricultural land and expanding urban labor markets. China's current agricultural population does not have the same opportunities.

\footnotetext{
${ }^{20}$ For instance, Jalan and Ravallion (2002) find that investment in both infrastructure and human capital in rural China has significantly raised the return to farmers' investment in physical assets (other factors held constant).

${ }^{21}$ According to Bai et al. (2006), the return to real capital has generally been highest in the eastern region, followed by the central region, and lowest in the western region. However, the dispersion has decreased over time.

${ }^{22}$ On basis of a computable general equilibrium (CGE) model, Whalley and Zhang (2007) find non-trivial redistributional effects of this type as a result of an assumed removal of the hukou.

${ }^{23}$ However, a faster outflow of young people from rural areas would leave some villages and small towns with mainly elderly people and a stagnating local economy.
} 
Moreover, a shift to private ownership of agricultural land is likely to improve the average factor income of farmers - in a similar way as the shift from collective farms to the so-called "household responsibility system”, and subsequently to family farms in the early 1980s. For instance, farmers would be encouraged to make long-term investments, including the amalgamation of land holdings, with a better exploitation of returns to scale as result. (Such results are particularly likely in the case of wheat, vegetables and animal products. ${ }^{24}$ ) Strengthened farmers' property rights - through a shift to outright ownership of land - would also improve the income security of farmers.

Thus, there seems to be a conflict between a lingering socialist ideology with respect to land ownership, on the one hand, and concern about long-term efficiency and per capita factor income among farmers, on the other hand. However, the existing distribution of political power is most likely another explanation to why ownership of land has not been privatized in China. As pointed out above, control over ownership of land is an important basis for financial gains among local politicians and public-sector administrators.

However, there may also be more altruistic arguments behind the reluctance of the Chinese authorities to privatize agricultural land. One might be that privatization could make the distribution of wealth gradually more uneven within the agricultural population (since some farmers are more able than others to gain by consolidating land holdings) - although the distribution of income and wealth among the Chinese population as a whole could very well become more even by such privatization. Another consideration might be that a shift to private ownership of land, and a subsequent consolidation of land holdings, could reduce the possibilities for migrants to urban areas to return to agriculture after having failed in the cities. There would simply be fewer family farms to receive them. This disadvantage would, however, be mitigated by the fact that private ownership of land would enable elderly farmers to transform their land into cash and, in turn, provide financial assistance to family members (probably mainly children) who did not "make it" in the cities.

In principle, price regulations are another conceivable method for influencing the distribution of factor income across population groups. Indeed, agricultural price regulations have been extensively used in many countries for this purpose. While developing countries have often

\footnotetext{
24 Already improvements in the transferability of land-lease contracts would facilitate such consolidation. Indeed, Wan and Cheng (2001, p. 191) estimate that consolidation of fragmented patches of land would raise labor productivity by as much as 12-17 percent, depending on the types of crops.
} 
implemented such regulations to keep down the prices of agricultural products, primarily to favor urban consumers at the expense of farmers, most developed countries have done just the opposite. There is no doubt that policies of the latter type have boosted revenues for the agricultural population, at least initially. But there are serious inherent problems in such policies. For instance, inefficient farms will survive more easily, thereby delaying the consolidation of land holdings and hence, the rationalization in the agricultural sector.

There are also well-known distributional problems associated with agricultural protectionism. Owners of large farms tend to be favored as compared to owners of small ones, since the latter consume a considerable fraction of the output from their farms themselves. Low-income consumers outside agriculture are also harmed relative to other consumers, since they use a larger sharer of their income to buy agricultural products. Thus, schematically speaking, there tends to be a redistribution of income from poor consumers to relatively affluent farmers. An alternative way of supporting farmers is, of course, tax concessions or direct subsidies to agriculture production - the so-called "low-price route" used, for instance, in the United Kingdom before the country's entry into EU. One well known advantage is that consumer prices would then be less distorted, in particular in an open economy. Another is that the burden on poor consumers would be smaller. Indeed, China has recently taken some steps along this "low-price route". I refer to the recent removal of the specific agriculture tax and experiments with production subsidies to farmers - probably partly in response to the depressing effect on the prices of many agricultural products in connection with China's accession to the WTO.

Price control in the housing market, mainly rent control, has also been frequently used in several countries to redistribute factor income across population groups. In particular, rent control may boost the income of tenants in apartment houses at the expense of landlords, at least temporarily. However, the disadvantages of such policies are also well known from experience in developed countries: excess demand for housing ("housing shortages”), black markets for rental contracts, deterioration in the quality of the housing stock, and a fall in new construction (which has often induced governments to start subsidizing housing construction). The distributional consequences among tenants are also rather dubious, since apartments in markets with a permanent housing shortage tend to be distributed through personal contacts with landlords and (capital-requiring) transactions on black markets - i.e. methods favoring high-income groups. As indicated above, after the mid-1990s, China has followed another route than increased rent control to favor (some) tenants, namely large- 
scale shifts from leasing contracts to ownership contracts on favorable terms, hence a privatization of apartments.

Generally speaking: if the Chinese authorities want to boost the factor income of low-income groups, it is likely that policies improving the productivity of these groups, alternatively production subsidies, are more promising instruments than price regulations. Not only are they more favorable for economic efficiency; they are also easier to target.

Naturally, not only the level but also the stability of the factor income of individuals is vital from a social point of view. In particular, this holds for the poorest segments of the population, since their margins in terms of misery are especially narrow. It is then natural to regard policies that smooth macroeconomic fluctuations as a first line of defense against factor income instability. ${ }^{25}$ In so far as stabilization policies have been pursued at all in China during the last decades, they mainly seem to have taken the form of direct quantitative regulations of investment and credit flows rather than general fiscal and monetary policy incentives. One reason is probably that public-sector firms have been regarded as quite insensitive to economic incentives. However, as the economic system in China gradually becomes more incentive-oriented, stabilization policy can increasingly rely on such incentives, which would reduce the conflicts between the stabilization and the allocation "branches” of economic policies.

\section{Tax/transfer arrangements}

The main purpose of tax-transfer programs is, of course, to make the disposable income of households more stable and more evenly distributed than factor income. What, then, are China's basic policy options in this field? One issue concerns the choice between (fairly) generous income-insurance arrangements for a narrow group of individuals and basic (safetynet) arrangements for the population as a whole. So far, the Chinese authorities have emphasized the former alternative. So what could a strategy with a broader coverage of tax/transfer arrangements look like? From an administrative point of view, unemployment insurance and pensions (the two major systems of income insurance) could certainly be extended to basically all employees in industry and services - in urban as well as in rural areas. Naturally, it is more difficult to organize similar systems of income insurance in

\footnotetext{
${ }^{25}$ On basis of a dynamic simulation model of the Chinese macroeconomy, Zhang (2001) reports that temporary external shocks tend to reduce the growth path of the economy for a considerable period of time (several years). Clearly, this is not unique for China.
} 
agriculture, since concepts such as income, unemployment and retirement are difficult to define and measure in this sector. However, improved crop-failure legislation and/or improved natural-disaster relief may to some extent fulfill similar functions. Moreover, in the case of pensions, a basic (or guarantee) lump-sum benefit should be administratively feasible not only in urban but also in rural areas. Indeed, this was the way pensions originally emerged in most of today's developed countries, in fact, even in urban areas.

There are also a number of country-specific problems in connection with China's emerging tax/transfer arrangements. One is that risk pooling often only takes place across limited geographical areas, such as a city, or possibly a province. At a first glance, this may seem to be a trivial problem, since the geographical domains of risk pooling are often more populous than many European nations. However, the composition of industries often differs strongly across geographical areas, so that payroll taxes, designed to finance the benefits, vary strongly across such areas. In particular, firms in areas with many unemployed or pensioners are exposed to much higher social costs than firms in other areas. For instance, payroll taxes are relatively high in regions with old industries, such as mining and steel, whereas they are relatively low in regions with new industries, such as banking, electronics and civil aviation. This tends to influence the relative competitiveness of firms in a rather arbitrary way, especially if local wages do not fully adjust to the differences in the payroll taxes. The limited area of risk pooling also reduces the portability of benefits, which impedes the emergence of a national labor market. Thus, de facto fragmentation of the social arrangements across the country has created problems for both the relative competitiveness of firms in different regions of the country and the mobility of labor. Therefore, in a longterm perspective, China may have a great deal to gain from further unifying the arrangements of income insurance across the entire nation.

Like several other countries, China has in recent years also experimented with a combination of pay-as-you-go (“paygo” for short) and funded pension systems - so far mainly covering urban citizens. However, both types of arrangements are likely to be confronted with financial problems in the future. Since the main problem in the paygo part of the pension system is closely related to the "graying" of the population, this specific problem could, in principle, be mitigated by a gradual increase in the effective retirement age. (The formal pension age today is 60 years for males and 55 for females, with an effective retirement age of only 55 for the former.) If this reform does not suffice, it may be combined with less generous benefits and/or higher contribution rates, although higher rates may be problematic 
since total payroll taxes are already quite high in urban sectors - about 40 percent, 30 percentage points being paid by the employer ${ }^{26}$.

A more specific problem for China is that contributions originally paid into the funded part of the pension system have, in fact, been used to finance deficits in the paygo part of the system - the problem of "empty individual accounts". As a consequence, the funded part of the mandatory pension system, so far, merely looks like another paygo system with "notional” (book-keeping) rather than real accounts. The Chinese authorities have basically to choose between two alternative strategies for dealing with this issue. One would be to altogether abandon the idea of funded individual accounts and be content with the paygo part of the system. The other alternative would be to "recapitalize" the accounts. One possibility would then be tax-financed capital injections into the accounts. Another possibility, suggested by Pieter Bottelier (2002), would be to let the National Social Security Fund take over the shares in a number of state firms. The fund could then be instructed to gradually sell the shares on the open market, at appropriate intervals to avoid strong negative effects on share prices. The revenues from the sales could then be used to recapitalize the empty individual accounts. In this way, two birds would be killed with one stone: a restoration of the individual accounts and a speed-up of the privatization of government-owned corporations. A more modest version of this idea has, in fact, already been implemented. The collective fund in China is entitled to receive 10 percent of the proceeds from sales of shares in state-owned companies every time there is an initial public offering (IPO), or a new share issue.

A more general problem with funded mandatory pension systems is whether the government should opt for government-operated or privately-operated funds. The latter alternative is, of course, more consistent with the notion of a decentralized and competitive market economy. Government-operated funds always run the risk of being "high-jacked" by politicians who might insist that they should decide on the portfolio policy of the funds, appoint the members of the board of the fund(s), and perhaps also appoint board members in firms where the funds own shares. China may then slip back towards more collective control and ownership of both assets and firms. Retreats may then be induced also in other dimensions of the economic system depicted in Figure 1, for instance through more centralized decisionmaking and more command in the production sector. 
The most promising way of significantly reducing the likelihood of such political intervention is probably to design a system where individuals are asked to place their mandatory pension savings in non-government funds of their own choice - although the government may continue to collect the pension contributions (taxes). Such reforms would also help create a broader and more active market for financial instruments, as a complement to the bank-dominated financial system that exists today in China. Considering China's recent tradition of government ownership and political intervention in individual firms, the risk (or "hope” among some observers) that a funded, government-created pension system will, in fact, result in a strongly nationalized economy is hardly less in China than in other countries.

\section{Human services}

After the breakdown of the pre-reform system of the provision of human services, the responsibility for such services has been shared among private agents, organizations affiliated with SOEs and local governments (31 provinces, 331 prefectures, 2109 counties and 44741 townships). In the case of education, the basic problem in China today is not that the services are currently provided by several different types of agents. Indeed, this pluralism on the supply side seems to have contributed to experimentation and variation in terms of curriculums and teaching methods (Hannum, 1999). Many observers seem to agree that the most pressing tasks today are instead to (i) expand the number of students from low-income families in secondary and tertiary education; (ii) reduce the financial burden of parents with children in school age; and (iii) improve the quality of education at all levels. Certainly, these tasks cannot be achieved without increased resources to education from the central government, including grants to local governments in poor areas of the country. Thus, the basic problem of the education arrangements in China seems to be the financing.

Naturally, China, like other countries, also has to deal with a number of organizational problems in the education system. One is to determine the number of years students should follow a single track and when (and how) students should be separated according to interest and ability (dual or multiple tracks). Another problem is the trade-off between "basic skills" (reading, writing and arithmetic) and broader, more vague "social abilities” (including preparation for civic duties and hobby activities). A third trade-off is between theoretical skills and vocational skills.

${ }^{26}$ China’s Social Security White Paper, 2006. 
In all these dimensions, it is probably a good idea to avoid extreme solutions. For instance, there is general agreement among specialists in education that early separation of schoolchildren (as, for instance, in Germany) into different tracks (in some countries as early as the fifth grade) disfavors children from homes without an academic background. Other countries have instead chosen a single-track system that extends through the ninth grade or even further, thereby emphasizing theoretical training that prepares a large share of a cohort of youngsters (sometimes as much as one-third or even half) for university studies. While problems associated with early separation are then avoided, the highly heterogeneous classes of students in the upper grades of the secondary school system have made it necessary to limit the intellectual ambitions in theoretical education. At the same time, students who are better fitted for, and show more interest in, vocational (rather than academic) training often have difficulties following such a highly theoretical education, with pacification and a large drop-out rate as a result. Moreover, several countries that have emphasized general "social abilities” rather than basic skills now seem to regret having done so. It is also interesting to note that many of today's rich countries did emphasize basic skills when they were poor 50 or 100 years ago.

Due to the uneven possibilities of parents to finance their children's schooling, and the uneven financial resources across local communities to offer high-quality education, China has, in fact, developed into a "multi-track" education system - in terms of years of schooling as well as quality. This threatens to create a highly polarized distribution of school achievement - across geographical areas as well as among individual households.

Like many other countries, China also has serious problems in the field of vocational training. Such training is today divided among SOEs, training centers affiliated with such firms, schools affiliated with the Ministry of Education (MOE) and, to some extent, schools connected with the Ministry of Labor and Social Security (MOLSS). ${ }^{27}$ However, there seem to be huge variations in the quality of this training. ${ }^{28}$ Deficiencies in quality in many places may explain why many individuals have recently chosen to finance their vocational training themselves. $^{29}$ China is, I believe, well advised to take inspiration from the German

\footnotetext{
${ }^{27}$ See, for instance, Fleisher and Wang (2001) and Li (2004).

${ }^{28} \mathrm{Li}$ (2004) reports many examples of poor supervision, considerable disorder and inefficiencies, as well as large mismatches between the demand for skills and the availability of training opportunities for different types of skills. The number of vocational schools has fallen gradually - in total by at least 50 percent - since the early 1990s.

${ }_{29}$ In a sample used by Li (2004), about a third of the individuals engaged in vocational training participated in programs mainly financed by out-of-pocket money.
} 
experience with apprenticeship work at firms, combined with general education at school (i.e., two days a week at school and three on the job, or the reverse). This could be accomplished without a very early separation of students into a two-track system (like in Germany). Many youngsters uninterested in, or not qualified for, academic education would then be able to make decent livings as craftsmen, and also feel pride in their specific skills. Indeed, the fast expansion of tertiary education as compared to (secondary) vocational education in China might indicate that authorities, students and parents overestimate the future (social and private) return on the former as compared to the latter type of education. ${ }^{30}$

It is even easier to identify basic deficiencies in health-care in China. The background is multifaceted: (i) the virtual collapse of health services in rural areas (services previously provided by agricultural communes and "barefoot doctors"); (ii) the inability of many SOEs to live up to their earlier responsibilities also in this field; and (iii) the absence of comprehensive health services for the rapidly increasing work force in the private sector. As in the case of education, the problem is not mainly that the private sector has taken over the responsibility for a considerable fraction of the production of services - in the case of sickcare about a third (Kin et al., 2002), although partly with the help of assets (medical facilities) rented from public-sector authorities. The basic problem is rather that the public sector has reduced, and decentralized, its responsibility for the financing of health care.

Despite the fact that China has recently (in 2004) spent as much as 5.6 percent of GDP on health care (Ministry of Health, 2006, Table 4-1), the deficiencies of the services are huge and well documented - a result of both inefficiencies and an uneven distribution of the services. ${ }^{31}$ One indication of both the inefficiencies and the inequalities is that about 80 percent of the health spending in recent years has been concentrated to large and mediumsized cities (Chow, 2006; UNDP 2000, p. 3). These allocations cannot possibly reflect the need for such services in the country as a whole. There are also serious problems of moral hazard in the health-care sector, including excessive medical examinations and unnecessary operations in many cases -required by patients or suggested by physicians; see, for instance, Eggelston et al. (2006).

\footnotetext{
30 The number of students in tertiary education increased by a factor of eight between 1985 and 2006, while the corresponding factor is three in the case of (secondary) vocational education. (NBS, 2006a, Tables 21-26) The population in age groups 18-21 enrolled in tertiary education was 3.4 percent in 1990, and it had increased to 21 percent in 2005 (Educational Statistics Yearbook of China, 2006, p. 15).

${ }^{31}$ The spending seems to be some 2-3 percentage points higher than in countries with a similar level of per capita income in Southeast Asia, except Vietnam (UNDP, 2005).
} 
As in many other countries, these inefficiencies are partly a result of the price system applied to the health sector. One example is the heavy reliance on fee-for-service, i.e., cost-pluspricing among sick-care providers. Experiences from other countries suggest that inefficiencies and moral hazard could be mitigated by a shift to prospective indemnity payments to providers (a standardized payment for each treatment), alternatively so-called "capitation" (advance payments based on the number of individuals for which the health care provider is responsible). Indeed, there seems to be a modest development in this direction in some places in China.

Another example of inefficient pricing is that the low (controlled) prices received by healthcare providers (“producers' prices”) for simple treatment have induced the providers to shift resources to more sophisticated and hence more expensive treatment, where the rewards to the providers are higher. Moreover, hospitals and health clinics have in recent years financed much of their health-care provision by revenues from hefty oversubscription and excessive pricing of drugs (Hesketh and Zhu, 1997; Eggleston, 2006). ${ }^{32}$ A more efficient price system in the health-care sector would, most likely, improve the allocative efficiency and favor the provision of basic health services. Clearly, considerably improved health-care in China as a whole also requires a relative shift of resources from urban to rural areas, as well as from affluent to poor urban areas. Realistically speaking, this cannot be achieved without more financial resources being transmitted from the central government to poor local governments. As in the case of education, this clearly requires an overhaul of the system of intragovernment transfers. On their way down to local governments, a considerable fraction of the money flows sent down from the central government to poor local governments has, in fact, tended to be siphoned off to powerful authorities - in more or less the same way as some Chinese rivers, which are full of water inland, turn out to be nearly dry when they reach the coast. ${ }^{33}$ Most likely, a fast and drastic improvement of health services in rural areas also requires a re-establishment of public and/or cooperative health clinics in these areas, since the return may not be attractive enough for private entrepreneurs. Indeed, health-care reforms along these lines are to some extent underway.

\footnotetext{
${ }^{32}$ According to Blumenthal and Hsiao (2005), as much as half of the total spending on health care consists of costs for drugs, while more normal figures in developed countries are usually 10-15 percent. Field studies suggest that only a modest fraction of the subscribed use of drugs has been medically motivated (Eggelston, 2006, pp 1-2)

${ }^{33}$ The distribution of per capita public spending across provinces seems to be at least as uneven as the distribution of per capita GDP, perhaps even more so (UNDP, 2005, p. 75); OECD, 2005b, Fig. 4).
} 
As in the case of pensions, the financing of future health-care insurance in urban areas is supposed to rely on a combination of paygo financing and funding (with individual accounts), the latter being organized along similar lines as in Singapore and Malaysia. ${ }^{34}$ Presumably, individual accounts are particularly useful for relatively inexpensive, mainly “out-patient”, treatment rather than expensive hospital treatment. Costly treatment (including “catastrophic health care”) would then have to be covered by the paygo (risk pooling) part of the system. The basic idea behind this mixed financing system is presumably that once the individual accounts have been depleted, the individual is supposed to pay from out-of-pocket money - until some income-related ceiling is reached, when financing from the paygo system takes over. However, the individual accounts in China already seem to have run into financial difficulties (similar to those in the pension system), thereby forcing the government to inject new money from the general budget into the paygo part of the system. ${ }^{35}$

In addition to the trade off between basic (relatively inexpensive) and more sophisticated (relatively expensive) health care, the authorities, of course, also have to deal with the tradeoff between preventive and curative care. As for developing countries in general, both ethical and efficiency concerns make a case for increased emphasis on preventive health services for broad population groups, rather than (specialized) curative health care for a minority of the population.

Whereas preventive health care in developed countries is mainly an issue of individuals' life style (smoking habits, diet, exercise, etc.), in poor countries it is also a matter of sufficient nutrition, sanitation and efforts by the authorities to combat transmitted diseases. Not least in China, it is also an issue of reducing exceptionally serious pollution and improving often miserable working conditions (Brajer and Mead, 2004; OECD, 2007). This is, of course, another important example of economic-social interaction in the country.

The Chinese authorities have recently tried to address the pollution problem by quantitative regulations and graduated charges when emissions exceed certain mandated ceilings. But many SOEs do not seem to be particularly sensitive to such charges, simply because profit

\footnotetext{
${ }^{34}$ An individual's entire contribution (two percent of the earnings) and a third of the contribution covered by the employer (six percent of the wage bill) are supposed to be paid into the individual's (funded) personal account, while the remaining two thirds of the employer's premium are allotted to the paygo part of the system (i.e., the common "health insurance pool").

35 The payroll tax that finances health insurance is currently 8 percent of the wage rate (OECD, 2005a, Table 4:3). Social Policy Research Centre (2002, p. 9) estimates that this figure would have to be considerably higher than 10 percent in the future to avoid deficits.
} 
considerations do not dominate their objectives. (This resembles the insensitivity of state firms to monetary and fiscal incentives in the context of stabilization policy.) There have, however, been recent experiments (conducted in cooperation with the World Bank) to exert social pressure on firms, rather than simply relying on quantitative restrictions and economic incentives. ${ }^{36}$ The basic idea of the latter types of policy measures is, of course, that firms' pollution behavior could be influenced by social norms, which are supposed to be upheld by the general public through its approval or disapproval. However, as in the case of corruption, the absence of politically independent media is bound to constrain the influence of the general public. In the future, when more firms in China are likely to be profit-oriented, it will be easier to pursue successful incentive-based policies to improve the environment by way of Pigouvian tax/subsidy programs, such as fees on polluters. When it comes to improvements of the work environment, experiences in today's developed countries suggest that legislation and inspection are effective tools, although experience-rated fees in work injury insurance are also potentially important.

In spite of the modest ambitions of social and environmental policies in China during the period of economic reforms, average life expectancy is rather high as compared to other countries with about the same per capita GDP. The level of adult literacy is also relatively high. Indeed, according to several cross-country evaluations, China ranks higher in terms of such aggregate “social” (or "human”) variables than in terms of per capita GDP - in spite of the rather low priority given to social and environmental policies during the reform period. ${ }^{37}$

There are at least three ways of explaining this apparent paradox. ${ }^{38}$ One could be that high life expectancy and widespread adult literacy, relative to the level of per capita income, were "inherited" from the pre-reform period, when widely distributed, although quite simple, health care and basic education were emphasized. As regards health, another explanation could be that China - more than other countries with a similar GDP per capita - has a recent history (after World War II) of promoting widespread sanitation and nutrition for broad population groups - factors that, on the margin, may have been more decisive for life

\footnotetext{
${ }^{36}$ One attempted method is to rank firms (publicly) according to their degree of environmental concern - the socalled “Green Watch Program” (Wang et al., 2004).

37 See, for instance, the Human Development Index, HDI, which is based on a number of broad economic and social indicators (UNDP, 2005, p. 81). Another source is the China Center for Modernization Research (2005).

${ }^{38}$ Nicholas Lardy brought this apparent paradox to my attention.
} 
expectancy than health care. ${ }^{39}$ These policies seem, to some extent, to have compensated for the modest increase in per capita income during the pre-reform period. Third, serious health effects of environmental damage may only emerge after rather long time lags (several decades). It may be added that both health conditions and the provision of health services in China vary dramatically across population groups, indeed, probably even more than in most other developing countries in Asia (Eggleston, 2006).

Moreover, "general” social policies - such as social insurance, education, sick care and pollution control - are not likely to be sufficient in dealing with "new" urban social problems such as those connected with the misuse of alcohol and drugs. Much more selective (targeted) social interventions are necessary in these cases. Perhaps China could mitigate some such problems by promoting the emergence of small and medium-sized cities as alternatives to ever-larger mega-cities. Medium size in this case might then be interpreted as cities with less than half a million people, rather than ten to thirty million.

A more general problem concerning the provision of human services is related to difficulties in providing effective mechanisms for adjusting quantities and qualities of human services to consumers' needs and preferences. In particular, in countries where local governments have a monopoly on the provision of human services, the "exit option" is not available as a means for consumers of exerting such influence (except possibly when moving to another municipality). The "voice option", exerted via the political system, is necessarily also rather weak in most countries, since citizens' political influence basically is limited to the right to choose among policy packages offered by political parties, rather than among specific services and/or service providers. Naturally, the voice option is particularly weak in nondemocratic societies, such as China. To strengthen the voice somewhat at the local administrative level, China has recently introduced elections of village leaders in some parts of the country (and in a few townships). There is some evidence that this reform has heightened the responsiveness of local authorities to the demands among citizens for public goods (Luo et al., 2007). But the extent to which such reforms will actually strengthen citizens' influence on the provision of human services would be expected to be limited without political democracy and competing political parties, and as long as centrally appointed party officials (party secretaries) have strong political power over local

\footnotetext{
${ }^{39}$ As we know, during the Mao period, the authorities were also responsible for the devastating famine in connection with the "Great Leap Forward" in the late 1950s and the early 1960s and the huge educational regress during the "Cultural Revolution" in the late 1960s and early 1970s).
} 
administrations. The absence of free media, of course, also seriously limits the advantages of local elections.

We would also expect that improved income insurance and increased tax financing of education and health care in the future would induce households to cut down on their huge savings (20-25 percent of disposable income). ${ }^{40}$ Individuals would then not only get welfare gains through better access to health care and education (for their children) but also through better consumption smoothing over time and higher lifetime consumption (since less precautionary saving would be necessary). As a side-effect, the huge surplus in the current account of the balance of payment would fall which, most likely, would reduce protectionist tendencies toward China in the rest of the world.

\section{Social policy trade-offs}

Clearly, China's strongly growth-oriented development strategy has brought about great social achievements in terms of increased household consumption for a huge part of the poor in the world. However, to be economically and socially sustainable during future decades, it is obvious that China has to shift to a development strategy that is much less energy consuming and much friendlier to the environment and to working conditions for employees. It is also well known that China's achievements have been quite modest in terms of the distribution and security of income and the provision of human services, such as education and health care outside a group of urban insiders. Indeed, the consumption of education and health care seems to be about as unevenly distributed as other types of consumption. ${ }^{41}$ Presumably, such policies do not only reflect the administrative difficulties of running social arrangements in rural areas; they also reflect the distribution of political powers in Chinese society.

It is tempting to speculate that risks of social unrest among disfavored population groups rural residents as well as the "floating population” in urban areas - will generate future shifts of relative political powers in favor of these groups, and that such shifts will result in greater emphasis on social issues among the political leaders. A future move towards political

\footnotetext{
40 The present GDP share of private consumption seems to be below 40 percent. (NBS, 2006b, Tables 3-13, p. 70. Government consumption (including government spending on education and health care) seems to be about 18 percent of GDP (NBS, 2006b, Tables 8-4 and Tables 8-5 p. 283).

${ }^{41}$ This seems to be the case for the distribution of per capita government spending on education and health across provinces, as well as for the distribution across income classes of individuals' spending on such services through out-of-pocket money. See NBS (2006a), tables in section 10 and table 21-26; and China Statistical Yearbook for Regional Economy (2006), tables in section 2. See also Zhang and Kanbur (2005).
} 
democracy and free media would certainly speed up such a process, and probably also result in more energetic attempts by the authorities to fight corruption and to improve the polluted environment and today’s miserable working conditions for many employees.

But what about the often asserted "grand" trade-off between more narrowly defined social policies (the distribution and stability of income, employment opportunities and the provision of human services) and "narrow" economic concerns (efficiency and growth)? The extent to which such trade offs actually emerge to a considerable extent depends on the methods used in social policies. Clearly, such conflicts may not be serious in the case of policies designed to boost the factor income of low-income families - for instance, through infrastructure investment in less developed regions and targeted policy measures that improve nutrition, sanitation, basic health care and education among poor families. Indeed, in some cases, such policies may be favorable also from a narrow (aggregate) economic point of view.

The risk of running into a "grand" trade-off is greater in the case of tax/transfer programs. Naturally, the more generous such programs are, the more difficult it is to avoid conflicts between social and narrow economic ambitions. However, such conflicts may to a considerable extent be mitigated by tight links between the individual's contributions and his/her expected future benefits, i.e., by creating strong actuarial elements in the systems. Naturally, there is a dilemma here: the tighter the link, the less redistribution of lifetime income across individuals there is.

When considering China's future options in the field of social reforms (in the narrow sense of the term), there are also important lessons to be learned from recent welfare-state experiences in developed countries. The most important positive lesson is perhaps that it is possible to provide quite ambitious social arrangements without ruining the possibilities of a continuation of steady GDP growth. There are, however, also negative lessons to be learned. The most obvious one is that serious disincentive effects on work may arise as a result of interactions between tax wedges on labor income and "moral hazard" in connection with social insurance and social assistance. In Western Europe, such problems seem to have been particularly severe in the case of unemployment benefits, sick-absence pay, and early retirement benefits (Lindbeck, 2006b). The problem is accentuated if individuals gradually develop a more "liberal" interpretation of their right to live on benefits from the government, rather than on work, i.e., if attitudes and social norms in favor of work, or against living off 
government benefits, are weakened. Outright benefit cheating is an extreme case. I have hypothesized elsewhere that contemporary welfare-state problems in developed countries are partly due to such changes in attitudes and social norms (Lindbeck, 1995; Lindbeck, Nyberg and Weibull, 1999). Indeed, today, about 20 percent of the population of working age in Western Europe live on various types of welfare-state benefits.

In view of the modest levels of taxation and social spending in China today, the country is not likely to encounter serious disincentive problems of these types in the near future. After all, total government budget spending in China today is only about 20 percent of GDP, as compared to 40-55 percent in several countries in Western Europe. However, if welfare-state arrangements gradually become more encompassing and generous in China in the future, there is no reason to assume that the country will be immune to such problems.

\section{References}

Bai, C., Hsieh, C. and Qian, Y. (2006). 'The Return to Capital in China’, NBER Working Paper No. 12755, NBER: Cambridge, MA, http://www.nber.org/papers/w12755

Blanchard, O. and Giavazzi, F. (2005). 'Rebalancing Growth in China: A Three-Handed Approach', CEPR Discussion Paper No. 5403, London, http://www.cepr.org/ pubs/new-dps/dplist.asp?dpno=5403\&action.x=12\&action. $y=8 \&$ action=ShowDP.

Blumenthal, D. and Hsiao, W. (2005). 'Privatization and its Discontents - The Evolving Chinese Health Care System', New England Journal of Medicine, 353(11), pp. 1165-1170.

Bottelier, P. (2002). 'Where is Pension Reform Going in China? Issues and Option', Perspectives, 3(5), Overseas Young Chinese Forum, http://www.oycf.org/ perspectives/17_063002/Pension_China.htm.

Brajer, V. and Mead, R. (2004). 'Valuing Air Pollution Mortality in China’s Cities', Urban Studies, 41, pp. 1567-1585.

China Center for Modernization Research (2005). China Modernization Report - A Study on Economic Modernization, Beijing: Chinese Academy of Sciences May 19, http://www.modernization.com.cn/cmr2005\%20overview.htm 
China Population Statistics Yearbook (2006). Beijing: China Statistics Press.

China’s Social Security White Paper (2006). China Internet Information Center, webmaster@china.org.cn

China Statistical Yearbook for Regional Economy (2006). Beijing: China Statistics Press.

Chow, G. (2006). “An Economic Analysis of Health Care in China”, mimeo, 5/7/ 06, Princeton.

---------. (2007). China's Economic Transformation, $2^{\text {nd }}$ ed., Oxford: Blackwell Publishing.

Economy, E. C. (2007). “The Great Leap Backward? The Costs of China’s Environmental Crisis”, Foreign Affairs, September/October, pp. 38-59.

Educational Statistics Yearbook of China (2006). Beijing: China Statistics Press.

Eggleston, K., Ling, L., Qingyue, M., Lindelow, M. and Wagstaff, A. (2006). 'Health Service Delivery in China: A Literature Review', World Bank Policy Research Working Paper No. 3978, Washington, DC, http://www-wds.worldbank.org/ external/default/WDSContentServer/IW3P/IB/2006/08/01/000016406_200608011 14229/Rendered/PDF/wps3978.pdf.

Fleisher, B. and Wang, Z. (2001). 'Skill Differentials, Return to Schooling, and Market Segmentation in a Transition Economy: The Case of Mainland China', Journal of Development Economics, 73(1), pp. 315-328.

Hannum, E. (1999). 'Poverty and Basic-Level Schooling in China: Equity Issues in the 1990s’, Prospects: Quarterly Review of Comparative Education, 29(4), pp. 561577.

Health Care Yearbook of China. (2006). Beijing: China Statistics Press.

Hesketh, T. and Zhu, W.X. (1997). 'Health in China: The Healthcare Market', British Medical Journal, 314, pp. 1616-20.

Jalan, J. and Ravallion, M. (2002). 'Geographic Poverty Traps? A Micro Model of Consumption Growth in Rural China', Global Development Network, Washington, DC, http://www.gdnet.org/pdf/580_Jalan.pdf.

Kin, L.M., Hui, Y., Tuohong, Z., Zijun, Z., Wen, F. and Yude, C. (2002). 'The Role and Scope of Private Medical Practice in China', mimeo, commissioned by UNDP, WHO and MOH China, http:/www.worldbank.org.cn/english/content/ Private_Medical_in_China.pdf.

Kuijs, L. and Wang, T. (2005). 'China’s Pattern of Growth: Moving to Sustainability and Reducing Inequality', World Bank Policy Research Working Paper No. 3767 (November) Washington D.C.: World Bank, http://www-wds.worldbank.org/ 
external/default/WDSContentServer/IW3P/IB/2005/11/08/000016406_200511081 54427/Rendered/PDF/wps3767.pdf.

Lange, O. (1938). 'On the Economic Theory of Socialism', Minneapolis: University of Minnesota Press.

Lardy, N. (2006). 'China's Domestic Economy: Continued Growth or Collapse?', in Bergsten, F., Bates, G., Lardy, N. and Mitchell, D. (eds.), China: The Balance Sheet, New York: Public Affairs.

Lau, L, Qian, Y., and Roland G. (2000). 'Reform without Losers: An Interpretation of China's Dual Track Approach to Transition', Journal of Political Economy, 108(1), pp. 120-143.

Lerner, A. (1934). 'Economic Theory and Socialist Economy’, Review of Economics and Statistics, II, pp. 51-61.

Lewis, A. (1954). 'Economic Development with Unlimited Supply of Labor', Manchester School of Economics and Social Studies, 22, pp. 139-191.

Li, M. (2004). 'Firm-based Training Programs and Workforce Developments in Mainland China', Report to World Bank Institute, Washington, DC.

Lindbeck, A. (1975). 'Economic Systems and the Economics of the New Left', in Der Streit um die Gesellschaftsordnung, Lectures at the University of Zurich, Zurich: Schulthess Polygraphischer Verlag, pp. 91-112.

------- (1995). 'Hazardous Welfare-state Dynamics', American Economic Review, 85(2), pp. 9-15.

------ (2006a). 'An Essay on Economic Reforms and Social Change in China', World Bank Policy Research Working Paper No. 0-3650, Washington, DC, http://papers.ssrn.com/sol3/papers.cfm?abstract_id=942159.

(2006b). 'Welfare State’, in The New Palgrave, Cambridge: Palgrave-Macmillan.

Lindbeck, A., Nyberg, S. and Weibull, J.W. (1999). 'Social Norms and Economic Incentives in the Welfare State', Quarterly Journal of Economics, 114(1), pp. 1-35. Luo, R., Zhang, L., Huang, J. and Rozelle, S. (2007). Elections, Fiscal Reform and Public Goods Provision in Rural China, paper presented at Chinese Economists Society, Shanghai, July 1-3, Journal of Comparative Economics, 35(3), pp. 583-611.

Maddison, A. (2003). The World Economy; Historical Statistics, Paris: OECD. http://www.theworldeconomy.org/publications/worldeconomy.

Maurer-Fazio, M. and Dinh, N. (2004). 'Differential Rewards to, and Contributions of, Education in Urban China's Segmented Labor Markets', Pacific Economic Review, 9(3), pp. 173-189(17). 
Ministry of Health (2005-2007). China Statistical Yearbook on Health, Beijing: China Statistics Press. http://www.moh.gov.cn/newshtml/18903.htm.

NBS (National Bureau of Statistics of China) (2005). China Statistical Yearbook, Beijing: China Statistics Press.

(2006a). China Statistical Yearbook, Beijing: China Statistics Press.

(2006b). China Statistical Abstract, Beijing: China Statistics Press.

------- (2006c). China Statistical Yearbook for Regional Economy, Beijing: China Statistics Press.

-------- (2007). http:wwww.stats. gov.cn/tjgb/qttjgb/qgqttgb/t20070518_402406314.htm.

OECD (2005a). Economic Surveys: China, Volume 2005/13, Paris: OECD.

OECD (2005b). OECD Review of Agriculture Policies - China, Paris: OECD.

OECD (2007). OECD Environmental Performance Reviews - China, Paris: OECD.

Ravallion, M. and Chen, S. (2007). ‘China’s (Uneven) Progress Against Poverty’, Journal of Development Economics, 82(1), pp. 1-42.

Social Policy Research Centre (2002). 'Reform of China’s Social Insurance System’, in Tuan, Y. (ed.), Social Policy in China, Beijing: Chinese Academy of Social Sciences.

Svensson, J. (2005). 'Eight Questions about Corruption', Journal of Economic Perspectives, 19, pp. 19-42.

UN, World Population Prospects (2006), http://esa.un.org/unpp.

UNDP (2000 and 2005). China: Human Development Report, New York: Oxford University Press.

Wan, G. and Cheng, E. (2001). 'Effects of Land Fragmentation and Returns to Scale in the Chinese Farming Sector', Applied Economics, 33, pp. 183-194.

Wang, H., Bi, J., Wheeler, D., Wang, J., Cao, D., Lu, G. and Wang, Y. (2004). 'Environmental Performance Rating and Disclosure: China's Green Watch Program’, Journal of Environmental Management, 71, pp. 123-133.

Whalley, J. and Zhang, S. (2007). 'A Numerical Simulation Analysis of (Hukou) Labour Mobility Restrictions in China', Journal of Development Economics, 83, pp. 392410.

World Bank (2004). Economic Report for 2006, World Bank, Washington, DC.

World Development Indicators (2006). World Bank, Washington, DC.

Xiaoyi, H. (1996). 'Reducing State-Owned Enterprises' Social Burdens and Establishing a Social Insurance System', in Broadman, H. (ed.), Policy Options for Reform of Chinese State-Owned Enterprises, Washington, DC: World Bank. 
Young, A. (2003). 'Gold into Base Metal: Productivity Growth in the People’s Republic of China during the Reform Period', Journal of Political Economy, 3(6), pp. 122061.

Zhang, X. (2001). 'External Shocks and the Long-term Growth of the Chinese Economy', in Lloyd, P. and Zhang, X. (eds.), Models of the Chinese Economy, Cheltenham, Edward Elgar, chap. 9.

Zhang, X. (2006). ‘Asymmetric Property Rights in China’s Economic Growth', Discussion Paper No. 28, International Food Policy Research Institute, Washington, DC, http://www.ifpri.org/DIVS/DSGD/dp/papers/DSGDP28.pdf.

Zhang, X. and Kanbur, R. (2005). 'Spatial Inequality in Education and Health Care in China', China Economic Review, 16, pp. 189-204. 